\title{
SELEKSI PSEUDOMONAD FLUORESEN SECARA LANGSUNG DI LAPANGAN UNTUK PENGENDALIAN PENYAKIT LINCAT PADA TEMBAKAU
}

\author{
Triwidodo Arwiyanto ${ }^{1}$, Fatma Yuniarsih ${ }^{2}$, Toekidjo Martoredjo ${ }^{3}$, dan Gembong Dalmadiyo ${ }^{4}$
}

\begin{abstract}
Field Screening of Pseudomonad Fluorescent for Controlling Tobacco Lincat Disease. Lincat disease is one of many factors which decreases tobacco production in Temanggung. The disease was caused by a combination between Ralstonia solanacearum and Meloidogyne incognita. The disease is difficult to control by any available control measures. The objective of this research was to find fluorescent pseudomonads which could suppress the lincat disease. The bacteria were isolated from local plants and tested in the field directly without any prior tests in the laboratory. The results indicated that dipping root system of tobacco for 20 minutes in the suspension of fluorescent pseudomonad suppressed lincat disease in the field. The results showed that there were variation in disease index between treatments. Plot treated with isolate pf22, pf23, pf30, pf42, pf51, and pf 83 showed the disease index of 16,67\%;13,34\%;20\%;20\%; 16,67\%; and $6,67 \%$, respectively. However, there was an inconsistency in the capability of the isolates in the disease suppression. At the second experiment, the plants treated with pf83 isolate showed the disease index of $36,6 \%$ with the control plot of $63,3 \%$. Laboratory tests indicated that there were 44 isolates which could inhibit pathogen growth in vitro. The fluorescent pseudomonads used in this experiments were proved not to belong to plant pathogenic bacteria.
\end{abstract}

Key words: biological control, fluorescent pseudomonad, tobacco, lincat disease

\section{PENDAHULUAN}

Tembakau merupakan komoditas perkebunan yang bernilai ekonomi tinggi di Indonesia sebagai salah satu sumber pendapatan petani maupun sebagai sumber pendapatan negara disamping mampu menyerap tenaga kerja yang banyak (Supriyanto dan Basuki, 2001). Salah satu jenis tembakau yang banyak diminati oleh para pabrikan rokok keretek di Indonesia adalah tembakau temanggung. Masalah yang muncul dalam budidaya tembakau temanggung yaitu adanya penyakit lincat yang disebabkan oleh kombinasi bakteri Ralstonia solanacearum dan nematoda Meloidogyne incognita (Dalmadiyo, 2004). Penyakit ini dapat menyebabkan kematian tanaman tembakau sebesar $50-60 \%$ dari total luas areal yang ditanam (Yulianti et al., 1999).

Berbagai cara pengendalian telah dilakukan namun belum memberikan hasil yang memuaskan (Yulianti et al., 1999; Dalmadiyo et al., 2000). Salah satu cara yang diharapkan dapat menurunkan penyakit adalah pengendalian secara biologi dengan menggunakan miroorganisme berupa bakteri pseudomonad fluoresen penghuni risosfer. Isolat pseudomonad fluoresen yang digunakan dalam penelitian ini merupakan isolat lokal yang diisolasi dari berbagai tanaman di Temanggung. Metode perolehan agensia hayati yang umum dilakukan oleh para peneliti adalah dengan melakukan isolasi calon agensia hayati, pengujian antibiosis in vitro, pengujian di rumah kaca, dan yang terakhir adalah pengujian di lapangan. Tulisan ini melaporkan hasil penelitian yang tidak mengikuti alur tersebut di atas. Isolat agensia hayati yang diperoleh di lapangan langsung diuji kemampuannya di lapangan tanpa melewati seleksi antagonisme in vitro. Hasilnya menunjukkan bahwa seleksi antagonisme langsung diuji di lapangan akan mendapatkan agensia hayati yang 'bekerja'(mode of action) melalui mekanisme selain antagonisme.

\section{METODE PENELITIAN}

\section{Bakteri dan kondisi kultur}

Ralstonia solanacearum. $R$. solanacearum diisolasi dari tanaman sakit yang diperoleh di Temanggung. Akar tanaman yang terinfeksi dicuci bersih dengan air mengalir. Epidermis akar dibuang dengan skalpel secara aseptis kemudian jaringan tanaman diusap permukaannya dengan $70 \%$ alkohol. Jaringan dipotong-potong dengan ukuran $5 \mathrm{~mm}$ dan dimasukkan ke dalam tabung reaksi berisi air steril. Suspensi bakteri yang terjadi kemudian digoreskan pada permukaan medium YPA (Yeast extract 5g,

\footnotetext{
${ }^{1}$ Dosen Jurusan Perlindungan Tanaman, Fakultas Pertanian Universitas Gadjah Mada Yogyakarta, Bulaksumur 55281

${ }^{2}$ Alumnus Jurusan Perlindungan Tanaman, Fakultas Pertanian Universitas Gadjah Mada Yogyakarta

${ }^{3}$ Dosen Fakultas Pertanian Universitas Sarjana Wiyata Tamansiswa Yogyakarta

${ }^{4}$ Peneliti Balai Penelitian Tanaman Serat dan Tembakau Malang (in memoriam)
} 
peptone $10 \mathrm{~g}$, agar $15 \mathrm{~g}$, $\mathrm{pH}$ 6.8) dan diinkubasikan selama 48 jam pada suhu kamar. Koloni $R$. solanacearum yang tumbuh dimurnikan dan disimpan untuk penelitian selanjutnya.

Pseudomonad fluoresen. Pseudomonad fluoresen koleksi dari Laboratorium Bakteriologi Tumbuhan Fakultas Pertanian UGM sebanyak 87 isolat ditumbuhkan secara terpisah pada medium King's B. Koloni yang tumbuh diperbanyak pada medium YPA miring kemudian disuspensikan dalam air steril sebelum digunakan dalam percobaan selanjutnya.

\section{Pengujian patogenisitas isolat pseudomonad fluoresen}

Secara terpisah semua isolat pseudomonad fluoresen ditumbuhkan pada medium YPA miring selama satu hari pada suhu kamar. Bakteri kemudian dipanen dan disuspensikan dalam $100 \mathrm{ml}$ air steril. Sebanyak $200 \mu \mathrm{l}$ suspensi bakteri tersebut diinjeksikan ke dalam ruang antarsel daun tembakau var. klemoko. Tanaman diinkubasikan pada suhu kamar selama 1 minggu. Gejala nekrosis serta gejala lain yang mengikuti diamati setiap hari. Secara paralel, tanaman tembakau diinokulasi dengan $10 \mathrm{ml}$ suspensi pseudomonad fluoresen/tanaman melalui akar. Tanaman diinkubasikan dan diamati perubahan yang terjadi pada tanaman tersebut. Sebagai kontrol tanaman diinokulasi pada akarnya dengan $10 \mathrm{ml}$ air steril.

\section{Penekanan penyakit lincat di lapangan}

Isolat pseudomonad fluoresen ditumbuhkan pada medium King's B selama satu hari pada suhu kamar kemudian disuspensikan dalam $100 \mathrm{ml}$ air steril. Bibit tembakau varietas klemoko umur 40 hari dicelup akarnya selama 20 menit dalam suspensi bakteri tersebut kemudian ditanam di lahan. Percobaan dilakukan dengan rancangan acak kelompok dengan 88 perlakuan. Setiap perlakuan diulang tiga kali, masing-masing ulangan terdiri dari 10 tanaman. Pengamatan terhadap penyakit lincat dilakukan setiap 10 hari sekali selama 40 hari setelah inokulasi. Percobaan dengan cara yang sama diulang sekali lagi di lahan yang berbeda dengan menggunakan isolat terpilih hasil percobaan sebelumnya. Percobaan di lapangan yang kedua ini menggunakan tiga konsentrasi bakteri antagonis yaitu

$\mathrm{K} 1$ = konsentrasi bakteri antagonis sama dengan konsentrasi yang digunakan dalam percobaan pertama, $\mathrm{K} 2=$ konsentrasi bakteri antagonis sepersepuluh $\mathrm{K} 1$ dan $\mathrm{K} 3=$ konsentrasi bakteri antagonis seperseratus K1

Intensitas serangan dihitung dengan rumus sebagai berikut:

$$
\begin{array}{ll} 
& \text { IS = A/N X 100\% } \\
\text { IS } & =\text { Intensitas Serangan } \\
\text { A } & \text { = Jumlah tanaman yang mati } \\
\text { N } & \text { = Jumlah tanaman yang diperlakukan }
\end{array}
$$

\section{Penekanan pertumbuhan patogen secara in vitro} Penekanan pertumbuhan Ralstonia solanacearum. Metode yang digunakan adalah seperti yang dikembangkan oleh Arwiyanto (1997b). Sebanyak tiga isolat pseudomonad fluoresen ditumbuhkan secara titik pada permukaan medium King's B dalam cawan petri. Setelah inkubasi selama 7 hari pada suhu kamar, cawan petri dibalik dan pada tutupnya dituangi $1 \mathrm{ml}$ chloroform. Setelah chloroform menguap semua, cawan petri dibalik dan pada permukaan medium dituangi dengan suspensi $R$. solanacearum dalam $0,6 \%$ agar air. Biakan diinkubasikan lagi selama 24 jam pada suhu kamar untuk kemudian diamati zona penghambatan yang muncul. Media agar yang berada dalam zona hambatan diambil secara aseptis kemudian dimasukkan ke dalam air pepton $0,5 \%$ dan dihancurkan dengan skalpel. Selanjutnya air pepton berisi agar tersebut diinkubasikan secara aerob pada suhu kamar selama 24 jam untuk melihat mekanisme penghambatan. Apabila air pepton menjadi keruh setelah inkubasi maka berarti di dalam media agar masih dijumpai sel sel bakteri patogen yang hidup sehingga penghambatan pertumbuhan bersifat bakteriostatik. Apabila setelah inkubasi, air pepton tetap bening tidak ada pertumbuhan bakteri maka berarti bahwa bakteri dalam media agar sudah mati sehingga penghambatan pertumbuhan bakteri bersifat bakterisidal.

Pengaruh suspensi bakteri antagonis terhadap telur Meloidogyne incognita. Pseudomonad fluoresen ditumbuhkan dalam medium yeast-peptone-glucose (yeats extract $5 \mathrm{~g}$, pepton $10 \mathrm{~g}$, glukosa $10 \mathrm{~g}, \mathrm{pH} 7,0$ ) secara aerob selama satu hari. Supernatant dipisahkan dengan massa bakteri melalui sentrifugasi selama 20 menit. Sebanyak 20-50 massa telur $M$. incognita diletakkan dalam cawan petri berdiameter $5 \mathrm{~cm}$ kemudian dituangi dengan $5 \mathrm{ml}$ supernatan. Jumlah 
telur sehat dihitung setelah inkubasi selama satu minggu pada suhu kamar.

\section{HASIL DAN PEMBAHASAN}

\section{Patogenisitas isolat pseudomonad fluoresen}

Sebelum dilakukan pengujian di lapangan, semua isolat pseudomonad fluoresen diuji kemampuannya dalam menimbulkan penyakit pada tanaman, khususnya pada tembakau. Dari hasil pengujian reaksi hipersensitif didapatkan bahwa semua isolat tidak menimbulkan gejala nekrosis pada daun tembakau. Hal ini menunjukkan bahwa isolat pseudomonad fluoresen tersebut bukan patogen tumbuhan. Pengujian inokulasi pada tembakau lebih menguatkan hal tersebut karena tidak dijumpai gejala malformasi apapun pada tanaman tembakau setelah diinokulasi dengan pseudomonad fluoresen melalui akar. Tanaman yang diinokulasi tampak sehat seperti halnya pada tanaman kontrol yang diperlakukan dengan air steril. Sebagian besar pseudomonad fluoresen bersifat saprofitik dan tumbuh di dalam tanah. Isolat pseudomonad fluoresen isolat Temanggung terbukti bukan merupakan patogen tumbuhan.

\section{Penekanan penyakit lincat di lapangan tahap pertama.}

Perendaman akar tembakau dalam suspensi pseudomonad fluoresen menunjukkan hasil yang berbeda beda tergantung isolat yang diaplikasikan, ketika kemudian ditanam di lapangan. Intensitas penyakit terendah ditunjukkan pada plot yang diperlakukan dengan isolat pf30 dan pf42 yaitu sebesar 26\%. Pada plot kontrol terlihat bahwa intensitas penyakit sebesar 53\% (Tabel 1). Meskipun

Tabel 1. Intensitas serangan penyakit lincat pada tanaman tembakau yang diperlakukan dengan pseudomonad fluoresen pada 40 hari setelah tanam

\begin{tabular}{|c|c|c|c|c|c|c|c|}
\hline $\begin{array}{l}\text { Perla } \\
\text { kuan }\end{array}$ & $\begin{array}{l}\text { Intensitas } \\
\text { Penyakit }(\%)\end{array}$ & $\begin{array}{l}\text { Perla } \\
\text { kuan }\end{array}$ & $\begin{array}{l}\text { Intensitas } \\
\text { Penyakit (\%) }\end{array}$ & $\begin{array}{l}\text { Perla } \\
\text { kuan }\end{array}$ & $\begin{array}{l}\text { Intensitas } \\
\text { Penyakit (\%) }\end{array}$ & $\begin{array}{l}\text { Perlaku } \\
\text { an }\end{array}$ & $\begin{array}{l}\text { Intensitas } \\
\text { Penyakit (\%) }\end{array}$ \\
\hline pf1 & 56,7abcdefgh & pf25 & 56,7abcdefg & pf49 & $36,7 \mathrm{abcd}$ & pf73 & $33,3 \mathrm{abc}$ \\
\hline pf2 & 56,7 abcdefgh & pf26 & 46,7 abcdef & pf50 & $60,0 \mathrm{abcdefgh}$ & pf74 & 73,3 efgh \\
\hline pf3 & $36,7 \mathrm{abcd}$ & pf27 & 46,7 abcdef & pf51 & $30,0 \mathrm{ab}$ & pf75 & 50,0abcdefg \\
\hline pf4 & 40,0abcde & pf 28 & 46,7 abcdef & pf52 & 53,3 abcdefg & pf76 & 60,0abcdefgh \\
\hline pf5 & 50,0 abcdefg & pf 29 & 46,7 abcdef & pf53 & $63,3 \mathrm{bcdefg}$ & pf77 & $53,3 \mathrm{abcdefg}$ \\
\hline pf6 & 56,7 abcdefgh & pf30 & $26,7 \mathrm{a}$ & pf54 & $40,0 \mathrm{abcde}$ & pf78 & 56,7abcdefgh \\
\hline pf7 & $90,0 \mathrm{~h}$ & pf31 & 53,3abcdefg & pf55 & 60,0abcdefgh & pf79 & 43,3abcdef \\
\hline pf8 & $83,3 \mathrm{gh}$ & pf32 & 50,0 abcdefg & pf56 & $43,3 \mathrm{abcdef}$ & pf 80 & 60,0abcdefgh \\
\hline pf9 & 46,7abcdef & pf33 & 40,0abcde & pf57 & 70,0 defgh & pf81 & 53,3abcdefg \\
\hline pf10 & 50,0abcdefg & pf34 & 46,7abcdef & pf58 & $43,3 a b c d e f$ & pf82 & 56,7 abcdefgh \\
\hline pf11 & 56,7 abcdefgh & pf35 & 53,3abcdefg & pf58 & $63,3 \mathrm{bcdefg}$ & pf83 & 40,0 abcde \\
\hline pf12 & 63,3 bcdefgh & pf36 & $60,0 \mathrm{abcdefgh}$ & pf60 & 50,0 abcdefgh & pf84 & $63,3 \mathrm{bcdefgh}$ \\
\hline pf13 & 46,7abcdef & pf37 & $36,7 \mathrm{abcd}$ & pf61 & 63,3bcdefgh & pf85 & $33,3 a b c$ \\
\hline pf14 & 46,7abcdef & pf38 & 46,7abcdef & pf62 & 60,0 abcdefgh & pf86 & 50,0abcdefg \\
\hline pf15 & 70,0 defgh & pf39 & $36,7 \mathrm{abcd}$ & pf63 & 56,7 abcdefgh & pf87 & $33,3 a b c$ \\
\hline pf16 & 66,7 cdefgh & pf40 & $36,7 \mathrm{abcd}$ & pf64 & 40,0abcde & pf88 & 46,7abcdef \\
\hline pf17 & 66,7 cdefgh & pf41 & 43,3abcdef & pf65 & 63,3bcdefgh & Kontrol & 53,3abcdefg \\
\hline pf18 & 70,0 defgh & pf 42 & $26,7 \mathrm{a}$ & pf66 & $53,3 \mathrm{abcdefg}$ & & \\
\hline pf19 & 46,7abcdef & pf 43 & 66,7 cdefgh & pf67 & 43,3abcdef & & \\
\hline pf20 & 46,7abcdef & pf44 & 43,3abcdef & pf68 & 46,7abcdef & & \\
\hline pf21 & 50,0abcdefg & pf45 & 66,7 cdefgh & pf69 & 50,0 abcdefg & & \\
\hline pf22 & $30,0 a b$ & pf46 & 76,7fgh & pf70 & 43,3abcdef & & \\
\hline pf 23 & $33,3 a b c$ & pf 47 & 70,0 defgh & pf71 & $70,0 \mathrm{defgh}$ & & \\
\hline pf24 & 50,0 abcdefg & pf 48 & 66,7 cdefgh & pf72 & 53,3abcdefg & & \\
\hline
\end{tabular}

Keterangan:

a. Angka merupakan rerata dari tiga ulangan

b. Angka yang diikuti huruf yang sama tidak berbeda nyata dalam uji Duncan pada taraf $5 \%$ 
plot kontrol intensitas penyakit relatif rendah yaitu sebesar 53\%, dapat dikatakan bahwa perlakuan dengan isolat pf30 dan pf42 mampu menurunkan intensitas penyakit yaitu dari $53 \%$ menjadi $26 \%$ atau terjadi penurunan intensitas penyakit sebesar $50 \%$. Pada perlakuan lain terjadi variasi intensitas penyakit pada akhir pengamatan. Pada skala intensitas penyakit 0-30\% ditunjukkan pada plot tanaman yang diperlakukan dengan isolat pf23, pf30, pf42, dan pf51. Pada skala yang lebih tinggi yaitu pada skala intensitas serangan $30-40 \%$ terdapat pada 13 perlakuan lainnya dengan isolat yang lain. Pada uji seleksi langsung ini diperoleh isolat-isolat pseudomonad fluoresen yang kalau diperlakukan pada tanaman membuat intensitas penyakit menjadi lebih tinggi. Hasil penelitian juga menunjukkan bahwa terdapat 29 perlakuan dengan intensitas serangan 40$50 \%$ dan sebanyak 42 perlakuan lainnya dengan intensitas serangan sebesar lebih dari 50\%. Hal ini dapat dikatakan bahwa tidak semua pseudomonad fluoresen penghuni risosfer dapat digunakan untuk mengendalikan penyakit bahkan dapat bertindak sebagai pengganggu tanaman (Cook \& Baker, 1983).

\section{Penekanan penyakit lincat di lapangan tahap kedua}

Berdasarkan intensitas penyakit yang rendah dibandingkan lainnya setelah diperlakukan dengan bakteri antagonis dari percobaan pertama maka dipilih enam isolat pseudomonad fluoresen untuk diuji kembali pada tahun tanam berikutnya. Keenam isolat tersebut adalah pf22, pf23, pf30, pf42, pf51, dan pf83. Hasil penelitian menunjukkan bahwa penekanan perkembangan penyakit terbaik adalah pada plot yang diperlakukan dengan isolat pf83 pada konsentrasi 1/10 dari konsentrasi awal. Intensitas penyakit yang muncul sebesar $26,7 \%$ sementara pada plot kontrol pada hari yang sama intensitas penyakitnya mencapai $63,3 \%$ (Tabel 2). Pengenceran yang lebih tinggi yaitu $1 / 100$ dari konsentrasi awal menyebabkan

Tabel 2. Intensitas Serangan Penyakit Lincat pada plot Tanaman yang diperlakukan dengan isolat terpilih pseudomonad fluoresen

\begin{tabular}{|c|c|c|c|c|c|}
\hline \multirow{3}{*}{$\begin{array}{l}\begin{array}{l}\text { Perlakuan } \\
\text { dengan isolat: }\end{array} \\
\text { pf22 }\end{array}$} & \multirow{2}{*}{ Konsentrasi } & \multicolumn{4}{|c|}{ Intensitas Serangan (\%) pada hari ke... setelah inokulasi: } \\
\hline & & 10 & 20 & 30 & 40 \\
\hline & K1 & $16,7 \mathrm{a}$ & $26,7 \mathrm{ab}$ & $40,0 \mathrm{bcd}$ & $40,0 \mathrm{ab}$ \\
\hline & K2 & $26,7 \mathrm{a}$ & $40,0 \mathrm{ab}$ & $60,0 \mathrm{~d}$ & $66,7 b$ \\
\hline & K3 & $23,3 \mathrm{a}$ & $20,0 \mathrm{ab}$ & $20,0 \mathrm{abc}$ & $33,3 \mathrm{ab}$ \\
\hline pf 23 & $\mathrm{~K} 1$ & $6,7 \mathrm{a}$ & $10,0 \mathrm{ab}$ & $13,3 \mathrm{ab}$ & $33,3 \mathrm{ab}$ \\
\hline & $\mathrm{K} 2$ & $6,7 \mathrm{a}$ & $23,3 \mathrm{ab}$ & $26,7 \mathrm{abcd}$ & $33,3 \mathrm{ab}$ \\
\hline & K3 & $6,7 a$ & $10,0 \mathrm{ab}$ & $30,0 \mathrm{abcd}$ & $46,7 b$ \\
\hline pf30 & K1 & $26,0 \mathrm{a}$ & $40,0 \mathrm{~b}$ & $50,0 \mathrm{~cd}$ & $53,3 \mathrm{~b}$ \\
\hline & $\mathrm{K} 2$ & $23,3 \mathrm{a}$ & $33, \mathrm{~b} 3$ & $40,0 \mathrm{bcd}$ & $40,0 \mathrm{ab}$ \\
\hline & K3 & $10,0 \mathrm{a}$ & $16,7 \mathrm{ab}$ & $33,3 \mathrm{bcd}$ & $46,7 b$ \\
\hline pf42 & $\mathrm{K} 1$ & $13,3 \mathrm{a}$ & $20,0 \mathrm{ab}$ & $26,7 \mathrm{abcd}$ & $43,3 \mathrm{ab}$ \\
\hline & K2 & $3,3 a$ & $6,7 \mathrm{ab}$ & $13,3 \mathrm{ab}$ & $53,3 \mathrm{~b}$ \\
\hline & K3 & $10,0 \mathrm{a}$ & $26,7 \mathrm{ab}$ & $20,0 \mathrm{abcd}$ & $40,0 \mathrm{ab}$ \\
\hline pf51 & K1 & $3,3 a$ & $6,7 \mathrm{ab}$ & $13,3 \mathrm{ab}$ & $63,3 b$ \\
\hline & K2 & $23,3 \mathrm{a}$ & $26,7 \mathrm{ab}$ & 26,7abcd & $46,7 b$ \\
\hline & K3 & $23,3 \mathrm{a}$ & $26,7 \mathrm{ab}$ & $30,0 \mathrm{abcd}$ & $36,7 \mathrm{ab}$ \\
\hline pf83 & K1 & $20,0 \mathrm{a}$ & $30,0 \mathrm{ab}$ & $30,0 \mathrm{abcd}$ & $50,0 \mathrm{~b}$ \\
\hline & K2 & $16,7 \mathrm{a}$ & $16,7 \mathrm{ab}$ & $23,3 a b c$ & $26,7 \mathrm{a}$ \\
\hline & K3 & $16,7 \mathrm{a}$ & $16,7 \mathrm{ab}$ & $30,0 \mathrm{abcd}$ & $40,0 \mathrm{ab}$ \\
\hline Kontrol & - & $10,0 \mathrm{a}$ & $10,0 \mathrm{a}$ & $30,0 \mathrm{abcd}$ & $63,3 b$ \\
\hline
\end{tabular}

Keterangan:

a. Nilai dalam tabel dalam bentuk persen rerata dari tiga ulangan. Untuk keperluan statistik, data ditransformasikan ke Arc Sin $\sqrt{ } \mathrm{x}$.

b. Angka yang diikuti dengan huruf yang sama pada kolom yang sama tidak berbeda nyata pada taraf $5 \%$ menurut uji Duncan 
kemampuan perlindungan isolat ini menjadi menurun dengan ditunjukkan oleh intensitas penyakit sebesar $40 \%$. Hal ini mungkin disebabkan makin sedikitnya fluoresen pseudomonad yang menempel pada permukaan akar tanaman yang diperlakukan. Sementara pada konsentrasi awal, justru intensitas penyakit yang ditimbulkan paling tinggi yaitu sebesar $50 \%$ yang tidak berbeda dengan intensitas penyakit pada percobaan setahun sebelumnya yaitu sebesar 40\%. Tingginya intensitas penyakit pada plot yang diperlakukan dengan konsentrasi awal ini mungkin dikarenakan terjadinya iritasi pada akar tanaman karena tingginya konsentrasi bakteri antagonis sehingga tidak memberikan perlindungan namun sebaliknya memperlemah tanaman. Konsentrasi yang tepat sangat diperlukan agar tanaman tidak menjadi melemah setelah diperlakukan dan memberikan efek pengendalian yang diharapkan seperti pada pengendalian penyakit layu bakteri tembakau cerutu dengan Pseusomonas putida strain Pf-20 (Arwiyanto dan Hartana, 1999; Arwiyanto dan Hartana, 2001).

\section{Penekanan pertumbuhan patogen secara in vitro}

Penekanan pertumbuhan $R$. solanacearum. Pengujian ini dilakukan untuk mengetahui apakah ada keterkaitan antara penekanan penyakit di lapangan dan penekanan pertumbuhan patogen secara in vitro. Dari 87 isolat fluoresen pseudomonad yang diuji ternyata tidak semua dapat menekan pertumbuhan $R$. solanacearum in vitro. Sebanyak 39 isolat mampu menekan pertumbuhan $R$. solanacearum dengan zona hambatan antara 5 sampai $15 \mathrm{~mm}$ (Tabel 3). Semua penghambatan in vitro ini bersifat bakteriostatik, artinya senyawa penghambat yang dihasilkan hanya menekan pertumbuhan $R$. solanacearum tetapi tidak mematikan bakteri tersebut (Madigan et al., 1997). Karena tidak mematikan $R$. solanacearum maka ketika pengaruh senyawa penghambat itu hilang,
$R$. solanacearum dapat melanjutkan pertumbuhannya yang tertekan sementara. Dari hasil pengujian tersebut di atas ternyata isolat-isolat pf23, pf42, pf51, dan pf83 tidak menunjukkan penekanan patogen secara in vitro namun mampu menekan perkembangan penyakit di lapangan. Weller (1988) menyatakan bahwa isolat antagonis yang mampu menekan patogen secara in vitro tidak selalu menjadi agensia hayati yang baik karena belum tentu dapat menekan penyakit di lapangan. Hal ini membuktikan bahwa seleksi langsung di lapangan memungkinkan mendapatkan isolat agenisa hayati yang dalam penekanan penyakitnya melalui mekanisme non antibiosis terhadap salah satu patogen penyebabnya.

Pengaruh suspensi bakteri antagonis terhadap telur Meloidogyne incognita. Penyakit lincat disebabkan oleh kompleks mikroorganisme yaitu $R$. solanacearum dan M. incognita (Dalmadiyo, 2004) sehingga dilakukan juga pengujian kemampuan pseudomonad fluoresen dalam menekan pertumbuhan nematoda. Seperti halnya pengujian terhadap $R$. solanacearum, pengujian ini ditujukan pula untuk konfirmasi ada tidaknya korelasi antara penekanan in vitro dan penekan penyakit di lapangan. Hasil penelitian menunjukkan bahwa semua isolat yang diuji mampu menekan pertumbuhan nematoda yang ditunjukkan dengan berkurangnya jumlah telur serta sedikitnya telur yang menetas menjadi larva (Tabel 4). Berkurangnya jumlah telur kemungkinan dikarenakan terdegradasinya masa gelatin selubung telur oleh aktivitas ensimatis. Semua isolat yang digunakan dalam penelitian ini mampu mencairkan gelatin secara in vitro (data tidak dipublikasikan). Selubung telur nematoda terdiri dari matriks gelatin yang mudah terdegradasi (Dropkin, 1996). Pseudomonas fluorescent dilaporkan mampu menghambat pertumbuhan dan penetasan telur Heterodera

Tabel 3. Penghambatan Pertumbuhan Ralstonia solanacearum oleh pseudomonad fluoresen secara in vitro

\begin{tabular}{ccc}
\hline $\begin{array}{c}\text { Zona Hambatan } \\
(\mathrm{mm})\end{array}$ & $\begin{array}{c}\text { Jumlah isolat pseudomonad fluoresen } \\
\text { yang menghambat }\end{array}$ & Mekanisme Penghambatan \\
\hline$<5$ & 48 & Bakteriostatik \\
$5-10$ & 13 & Bakteriostatik \\
$10-15$ & 10 & Bakteriostatik \\
$>15$ & 16 & Bakteriostatik \\
\hline
\end{tabular}


Tabel 4. Pengaruh Perendaman dengan Supernatan Pseudomonad fluoresen terhadap massa telur Meloidogyne

\begin{tabular}{lcccc}
\multicolumn{2}{c}{ incognita } & \multicolumn{3}{c}{ Populasi Akhir } \\
\cline { 2 - 5 } Isolat & \multicolumn{2}{c}{ Populasi Awal } & Telur & Larva \\
& Telur & Larva & $3 \mathrm{a}$ & $4 \mathrm{a}$ \\
pf22 & 42 & 1 & $1 \mathrm{a}$ & $2 \mathrm{a}$ \\
f23 & 34 & 0 & $3 \mathrm{a}$ & $2 \mathrm{a}$ \\
pf30 & 40 & 1 & $7 \mathrm{~b}$ & $3 \mathrm{a}$ \\
pf42 & 31 & 0 & $17 \mathrm{c}$ & 0 \\
pf51 & 50 & 0 & $11 \mathrm{~b}$ & 0 \\
pf83 & 33 & 0 & $0 \mathrm{a}$ & $26 \mathrm{~b}$ \\
Kontrol & 26 & 0 & & \\
\hline
\end{tabular}

Keterangan:

Nilai dalam tabel adalah rerata dari tiga ulangan. Angka yang diikuti dengan huruf yang sama pada kolom yang sama tidak berbeda nyata pada taraf $5 \%$ menurut uji Duncan.

crucifera (Aksoy \& Mennan, 2004).

Data pada Tabel 4 menunjukkan bahwa pseudomonad fluoresen yang diuji dalam penelitian ini mampu menekan petumbuhan nematoda puru akar sebagai salah satu agensia penyebab penyakit lincat. Dengan menurunnya populasi nematoda maka resiko kemunculan penyakit lincat dapat berkurang. Meskipun banyak dilaporkan bahwa $R$. solanacearum dapat secara soliter mampu menimbulkan penyakit berupa penyakit layu (Arwiyanto, 1997a) namun dengan adanya nematoda puru akar akan semakin memperparah gejala. Dengan demikian pengendalian nematoda akan sangat berarti dalam program pengendalian penyakit layu bakteri. Dalam konteks penyakit lincat dimana patogennya merupakan kedua mikroorganisme tersebut di atas maka menurunnya populasi nematoda karena aksi agensia hayati akan menurunkan kematian tanaman akibat penyakit tersebut.

Isolat-isolat pseudomonad fluoresen seperti pf22, pf23, pf30, pf42, pf51 dan pf 83 merupakan isolat yang prospektif untuk dikembangkan lebih lanjut. Dalam program pengendalian biologi penyakit tumbuhan, penggunaan lebih dari satu jenis isolat akan memberikan efek perlindungan yang lebih baik (Cook \& Baker, 1983). Dengan demikian kombinasi dari isolat-isolat ini dengan agensia pengendalian biologi yang lain seperti strain avirulen dari $R$. solanacearum (Hertanto et al., 1997) diharapkan dapat meningkatkan kemampuannya dalam menekan penyakit layu bakteri di lapangan.

\section{SIMPULAN}

Meskipun tidak ada beda nyata secara statistik dalam penekanan penyakit lincat di lapangan, isolat pf83 ada kecenderungan menunjukkan penekanan intensitas serangan yang lebih besar dibandingkan dengan isolat lainnya.

\section{SANWACANA}

Tulisan ini merupakan sebagian dari hasil penelitian Riset Unggulan Terpadu XI yang didanai oleh Menristek dengan surat perjanjian Nomor 03/Perc/Dep.III/RUT/PPKI/II/2005 tanggal 1 Februari 2005. Untuk semua itu, penulis mengucapkan banyak terima kasih.

\section{DAFTAR PUSTAKA}

Aksoy, H.M. \& S. Mennan.2004. Biological Control of Heterodera cruciferae (Tylenchida: Heteroderidae) Franklin 1945 with Fluorescent Pseudomonad. Journal of Phytopathology $152: 8-9$

Arwiyanto, T. 1997a. Pengendalian Hayati Layu Bakteri Tembakau Cerutu di Sumatera Utara Secara Terpadu. Ekspose Hasil Penelitian Tembakau Deli IV. Medan. 34p

Arwiyanto, T. 1997b. Biolocal Control of Tobacco Bacterial Wilt: 1. Isolation of Antagonistic Bacteria. Journal of Indonesian Plant Protection 3: 54-60 
Arwiyanto, T. \& I. Hartana. 1999. Pengendalian hayati penyakit layu bakteri tembakau (Ralstonia solanacearum).2. Percobaan di rumah kaca. Journal of Indonesian Plant Protection 5: 50-59.

Arwiyanto, T. \& I. Hartana. 2001. Percobaan lapangan pengendalian hayati penyakit layu bakteri tembakau (Ralstonia solanacearum). Mediagama 3:7-14.

Cook, R.J. \& K.F. Baker. 1983. The Nature and Practice of Biological Control of Plant Pathogens. American Phytopathological Society. St Paul. Minnesota. 539p.

Dalmadiyo, G., S. Rahayuningsih, \& Supriyono. 2000. Penyakit Tembakau Temanggung dan Pengendaliannya. Monograf Balittas No. 5. Balai Penelitian Tembakau dan Tanaman Serat. Malang. 10p.

Dalmadiyo, G. 2004. Kajian Interaksi Infeksi Nematoda Puru Akar (Meloidogyne incognita) dengan Bakteri Ralstonia solanacearum pada Tembakau Temanggung. Fakultas Pertanian UGM. Disertasi. 123p.
Hertanto, S.C., T. Arwiyanto \& T. Martoredjo. 1997. Biological Control of Tobacco Bacterial Wilt with Avirulent Strains of Pseudomonas solanacearum. Proceeding of Scientific Seminar and XIV Congress of Indonesian Phytopathological Society. Palembang Indonesia. Oktober 25-27, 1997. In Indonesian.

Madigan, M.T., J.M. Martinko, \& J. Parker.1997. Biology of Microorganisms. Prentice Hall International, Inc.

Supriyanto, S.L. \& H. Basuki. 2001. Pemasalahan Pengembangan Tembakau di Jawa Tengah. Prosiding Lokakarya Pengembangan Agribisnis Tembakau. Malang. 6 November.

Weller, D.M. 1988. Biological Control of Soilborne Plant Pathogens in the Rhizosphere with Bacteria. Ann.Rev.Phytopathol. 26:379-407

Yulianti, T., N. Ibrahim, \& G. Dalmadiyo. 1999. Pemanfaatan Mikroba Antagonis untuk Mengendalikan Penyakit Lincat. Prosiding Kongres Nasional XV dan Seminar Ilmiah PFI. Purwokerto. 16-18 September 1999. 